Siegenthaler, Fiona (2016): "Playing Around with Money: Currency as a Contemporary Artistic Medium in Urban Africa"

In: Critical Interventions: Journal of African Art History and Visual Culture 10(2), pp. 135-153. Issue editor Jordan A. Fenton.

http://www.tandfonline.com/doi/full/10.1080/19301944.2016.1205345.

\title{
Playing Around with Money: Currency as a Contemporary Artistic Medium in Urban Africa
}

Fiona Siegenthaler, University of Basel

In recent years, artists in African cities have shown a striking inclination to use money as a medium for artworks. Money is applied as sculpting material, it is a means of transaction in happenings and a prop in performance videos, and it has a symbolic and iconic function in paintings and installations. It is a marker of both, autonomy and dependence. While it stands for national identities, politics and economies, it also represents a global connectivity with its advantages and pitfalls. The paper presents three artists working in African cities and the diaspora who use money in a variety of ways: Meschac Gaba, Donna Kukama and Gerald Machona. After a close analysis of a selection of their work, it considers the artists' own place within an internationalizing art world and art market that perhaps is particularly welcoming to the seemingly 'universal' symbolic and economic nature of money.

\section{Keywords:}

Money as an artistic medium; Currency; Contemporary African art; Urban Africa; Meschac Gaba; Donna Kukama; Gerald Machona; Transnational art practice; Globalization; Inflation; Art market; Painting; Object; Installation; Performance; Video art 


\section{Playing Around with Money: Currency as a Contemporary Artistic Medium in Urban Africa}

Fiona Siegenthaler, University of Basel

\section{Introduction}

While every artist is involved in some kind of economic flow, -even if some try to escape its logic-few explore the materiality of currency. In recent years, however, contemporary art production in African cities and the diaspora reveals a striking inclination to employ money as an artistic medium. The use of currency in contemporary art varies, ranging from the incorporation of devalued banknotes into a canvas painting, as with the case in Meschac Gaba's early work, to a more conceptual approach as seen in Mansour Ciss' and Baruch Gottlieb's proposal of a future AFRO currency at the Dakar Biennial in 2002. Between the representational and conceptual polarity, money is also used as a sculptural material, a medium of exchange in happenings and performances, a prop in performance videos, and for its iconic and symbolic purpose in two- and three-dimensional formats. Money is employed by artists to reflect on the relationship between contemporary Africa and global economies, their often unpredictable dynamics and malcontents. Finally, the use of money allows artists to explore their own role in a globalized monetary system that drives the international art market in which they endeavor to participate.

In the following essay, I discuss three artists who have introduced money into their work: Meschac Gaba, Donna Kukama, and Gerald Machona. Analyzing selected works, the paper looks at the intrinsic meaning and function of money as a material, a medium, and as an icon. Although some aspects in the use of money are common to all three artists, I emphasize the differences in terms of materiality and artistic process.

Although money circulates globally, currencies take on different meanings in particular political and economic contexts. Africa's history is rife with examples of cowry shells, glass beads, iron rods, bronze anklets, gold dust or textiles used as currencies and luxury items that were once exchanged, pawned, traded or stored 
as family heirlooms. Often, these commodities were introduced into ritual practice and became part and parcel of a complex symbolic visual language. $19^{\text {th }}$ century Bamum royal thrones or the brass $i k e g o b o$ in $18^{\text {th }}$ century Benin kingdom were decorated with beads that emphasized the spiritual and political power and the related wealth of their owner (Geary, 2011; Ben-Amos, 1999). ${ }^{1}$ In the first half of the $18^{\text {th }}$ century, Oba Eresoyen even owned a "house of cowrie shells" which in today's terms is akin to "wallpapering it [the house] with dollar bills" (Ben-Amos, 1999:123). From early on, currencies were used for more than bartering. They are integral part of material culture and the arts (Blier, 1998; Guyer, 1995; Perani \& Wolff, 1999).

Different to a dominant perception of modernity as a rupture to earlier cultural practices, money still today proves to be a highly adaptive and popular medium for artistic practice. In their largely standardized and globally accepted form, contemporary paper currency and coins take on this material, symbolic and artistic aspect. As a part of artworks by contemporary African artists, they mostly represent both the independent national monetary system of their country and simultaneously the dependence of many African economies on foreign markets and constituents. Money thus becomes a marker of political and economic crisis as much as it reflects the desire to participate in the global economy. In a more positive light, the use of money speaks to transnational and global connectivity as well as the chance of a future free of financial worries. Paradoxically, money is the asset most societies rely on for their economies, although it is subjected to unpredictable dynamics and instability—-the latter being its "single most important aspect", according to Jane Guyer (1995a, p. 3). Most often, African artists working with currency as their primary medium exploit precisely this instability of African economies and the volatile role money plays therein. Money as a social and economic asset or lack thereof, and as a cause of many political and social conflicts, is a medium, symbol and material chosen by artists who try to engage the lived realities in African cities within ever expanding global financial markets.

My discussion of money in contemporary African art is structured in three parts. In the first part, I look at Meschac Gaba's early work of the mid to late 1990s in which money figures as an objet trouvé and a modeling compound for his 
sculptures, objects and installations. In the second section, Donna Kukama's performances involving economic transactions and transformations of money and values are discussed as adapting but also wittily questioning the logics of financial markets. In a third section, Gerald Machona's work is analyzed with regard to the iconic function of his use of the wildly unstable Zimbabwean dollar.

Money, in its material form, its symbolic quality, iconic stature and role as a universal currency around the world, is accessible to a broad audience. Especially when used as an artistic medium, it allows viewers from all over the world a universal interface to local as well as global political, economic and cultural issues, national and transnational identities, and systems of value and power. Therefore, even when artists speak of national or regional economies and aesthetics, they address an international audience. This is discussed at the end of this paper, where I reconsider the three different artistic treatments of money, inserting them into a broader discussion of contemporary art practice in relation to the artists' own position within the global art market. The artists find themselves in an intermediate position between regional and international economies and interpretational frameworks. When their work enters the art circuit, it adopts its own logics of mediation, materiality and transaction.

\section{Money as an Objet Trouvé and an Artistic Material}

Meschac Gaba (born 1961 in Cotonou, Benin) was the first of the three artists discussed here to work primarily with money as a found artistic material. Today, he is mainly known for his Museum of Contemporary African Art, developed in the 1990s during his studies at the Rijksakademie voor Beeldende Kunsten, Amsterdam. ${ }^{2}$ The project is recognized today as an important conceptual work that scrutinizes the notion of African art and the museum as an institution. It has its beginnings in a more material-based work that Gaba had started in his early years in Cotonou and that has left its traces in some of the Museum spaces such as the Game Room, the Salon, the Museum Shop, the Library, and the Summer Collection. The Draft Room in particular represents the conjuncture of both a conceptual and material approach of Gaba because it initiates the twelve-part series of spaces Gaba developed for the Museum of Contemporary African Art in 
Amsterdam and at the same time includes objects related to the work he had done in Cotonou (Gaba et al., 2001; Greenberg, 2013; Siegenthaler, 2004). During his apprenticeship in Cotonou, at the workshop of Gratien Zossou, Gaba mainly practiced painting. The inflation in the early 1990s, and the strategic debasement of the CFA in 1994, resulted in a surplus of devalued CFA notes. This had a profound effect on Gaba's approach to painting with the introduction of paper money into his images. Not unlike collage, currency notes were integrated into the paintings, becoming a crucial medium carrying relevant social and economic messages. The abstract character of his images enhances the iconic quality of the banknotes that occupied prominent positions in his compositions. He also introduced round cutouts of banknotes into his paintings, lending them the character of decorative coins. ${ }^{3}$ Paper money furthermore covers his wood objects of the mid-1990s that oscillate between image and sculpture. The bank notes conceal the wooden nature of the object, but rather than working as an emblematic icon, they seem to play the role of a colorful and extraordinarily cheap surface material in a time of financial crisis.

Thus, bank notes entered Gaba's artwork as did found nails, strings, beer tops, wood, or canisters in the artworks of his contemporaries like António Ole, El Anatsui or Romuald Hazoumè, in which objets trouvés are recycled and turned into something new by being integrated into an artistic composition. This process of recycling, or récupération, often associated with a controversial idea of distinctive African aesthetics (Grabski, 2009), is intensified from the mid-1990s on when Gaba starts his studies at Rijksakademie voor Beeldende Kunsten in Amsterdam.

In Gaba's later work, and especially in the Museum of Contemporary African Art, money adopts a stronger significance as a symbol for geo-political competition, as in his Dame game, where the opposing tokens, covered by US Dollars and Euros respectively, can be identified as representing the United States and Europe as geo-political adversaries. ${ }^{4}$ On the other hand, Gaba continues using bank notes as an actual material that is shredded so thoroughly that the original material basis-paper money_becomes unrecognizable. Piles of shredded paper are either presented as such-shredded paper heaps_or they are shaped into a new form (Fig. 1). The shredded money is at times also carefully filled into transparent 
plastic bags similar to how produce are carried and transported to and from markets in most African cities (Fig. 2). This process emphasizes the material qualities of money. The confetti-like money paper is used not unlike a modeling compound to create inscrutable cylindrical objects and beads for design items such as necklaces. ${ }^{5}$

By shredding and reshaping paper money, Gaba thus produces new objects reminiscent of earlier forms of currency such as chains of beads made from glass pearls or ostrich eggs. At the same time, the process also reminds us of how paper money is handled in times of hyper-inflation when the single banknote no longer means anything and transactions depend on the management of mass rather than value. ${ }^{6}$ Gaba's reconfigured objects at times act as items for sale within the exhibition context, as is the case with multiples that were sold as part of a series or edition in the Museum Shop. In this sense, they do not only reflect on the material value-transformation of paper money, but also their different ways of 'functioning' within the art system.

\section{Transactions and Transformations of Monetary and Symbolic Values}

Meschac Gaba's currency-infused artworks comment on the production of cultural value in the artworld and make use of this very value generation in some of his installations. He often refers to contemporary and colonial power relations in a globalized market system that not only affect the value of currencies but also of the appreciation of cultural achievements. For instance, he attached devalued CFA bank notes in the room plants included in the Architecture Room-but not without first inserting elements that normally do not show up on African banknotes. Where normally the head of state or national symbols from fauna and culture are reproduced, the portrait of Pablo Picasso instead gazes at us (Fig. 3). By inserting the portrait of one of the most renowned European artists who was inspired by African sculpture, Gaba comments on an infamous intercultural exchange during the colonial era. In so doing, he illustrates the colonial power structure, where the cultural achievements of the colonized were often destroyed or appropriated by the colonial powers in order to establish their own supremacy. These power politics were negotiated through the arts as much as in the political and economic sphere. 
In a similar way, values are generated within the art system today. Through the work of the art market, an artwork's value increases significantly_along with its material and aesthetic account. One can argue, it achieves a kind of surplus value the moment it becomes an artistic product. Artists consciously play with and comment on this transformation of monetary value through societal and cultural appreciation, which in turn, is demonstrated through increasing art market prices.

Gaba's work criticizes the close correlation between dominant money markets and cultural hegemony, but his work does not avoid this system of value generation. On the contrary, he made use of it in order to contribute to the livelihood and career of up-and-coming artist friends by inserting their work into European exhibition spaces and the institutionalized value system. For instance, the objects in the Museum Shop he exhibited in Kunsthalle Bern (Switzerland), at the National Museum in Accra (Ghana), the S.M.A.K in Ghent (Belgium) or at documenta 11 in Kassel (Germany), were for sale. The Museum Shop is thus not just an installation but is in fact a selling booth consisting of moderately prized objects and trinkets produced by the artist (some of which are his shredded money objects) and his artist friends. Such objects are boldly sold within the exhibition space. However, Gaba's profit margin is different from typical gallery owner/artist agreements since he does not charge a commission. In its attempt to bring into question the capitalist system, the Museum Shop functions in a manner similar to Gaba's Humanist Space where bicycles are rented out at a low rate while the revenues are dedicated to NGOs in Africa (Greenberg 2013, p. 130). With his overt use of financial transactions in this installation, Gaba exposes the interdependence of the arts markets with other markets on the one hand, and the mechanisms of contemporary art institutions as value generators on the other. Gaba's material transformation from banknotes to shredded paper, essentially a shift from monetary value to the symbolic, is a statement on the ways in which art institutions and the globalized art world have become the driving force in the production of value in formal art sectors.

Donna Kukama (born 1981 in Mafikeng, South Africa) ${ }^{7}$ also incorporates money in her performance work, albeit not always, and it does not adopt an iconic 'signature' effect as it tends to do in Gaba's work of the 1990s. Rather, she 
employs it temporally, with site-specific performance interventions. Money, and especially coins, are deployed in order to refer to rather abstract and poetic transactions. They are part of a performative strategy to softly disrupt everyday social interactions and transactions, opening up momentary occasions for viewers to see their own (inter-)actions and the world differently. In the following discussion, I examine three performances of Kukama where money transaction represents a key element. While it is rather implicit in The Swing (After After Fragonard; 2009 [sic]) it is more prominently at stake in the Black Money Market (2010) and the Investment Bank of Elsewhere (2012).

The Swing (After After Fragonard; Fig. 4) was a performative intervention that took place in 2009. Kukama fastened a swing to a motorway bridge crossing above the Mai-Mai market, which is located in the eastern end of the inner city of Johannesburg and is known for catering to a predominantly African clientele. Traders sell there a broad range of African produce, especially Muti ('traditional' medicine) to a predominantly male clientele. ${ }^{8}$ Kukama chose the location for her swing on her own initiative following an invitation by the Spring Art Tour to conceptualize a performance to unfold in a neighboring part of the city, the strongly gentrified Maboneng district. Struggling with the harsh contrast between this exclusive art island and the economic and social realities of the adjacent market, she decided to change the location to the Mai-Mai known for its rather informal and particularly 'African' flair. She sought to speak to and challenge the economic disparity that defines the immediate vicinity of Jeppestown and Maboneng. Her Swing is an obvious reference to the famous Rococo painting (1767) by JeanHonoré Fragonard and Yinka Shonibare's reinterpretation of it (The Swing After Fragonard, 2001). The French version featured a young affluent lady buoyantly rocking her swing. An elderly man in the background pushes the swing while a young man seemingly hides in the bushes, trying to steal a glimpse under her flowing dress as she loses her shoe. Kukama blended this Rokoko imagery of ignorant aristocratic leisure and abundance into the harsh realities of a trading place just under the flyway and thus alluded to two issues, namely the social inequalities apparent in gentrification trends and the vulnerability of women in contemporary South African society. 
The frivolous and playful demeanor of the male gaze solicited by the women's revealing posture appears rather innocent when compared to the frequent incidents of male encroachment on the female body in South Africa. ${ }^{9}$ Just some months before Kukama's intervention, a young woman wearing a mini-skirt was physically attacked and molested by taxi drivers at the Noord taxi rank for being dressed too provocatively. Seesawing above the market, Kukama's reenactment of The Swing would no doubt attract the gaze of the male clientele and therefore somewhat provocatively comment on that incident. At the same time, she remains beyond their reach, performing both a gendered statement as well as a poetic act far above their heads and the economy-driven market.

Adding to the absurdity of the situation, swinging below the bridge and above the Mai-Mai market, Kukama threw money down. 10-Rand notes (equivalent to ca. 1 Euro) wafted softly onto the ground and into the hands of attentive spectators. She seemed mis-placed in a double sense, firstly as a seemingly rich person playfully distributing money in a market, secondly as a frivolously dressed woman above the heads of men. She thus subverted the value exchange mostly connoted with the availability of female favors. Here, the female offers both, the view on her graciously dressed body and a financial gain for the men. ${ }^{10}$ With her decision to incorporate real money, especially in the manner in which she did within a market context, she elicited a type of symbolic and performative action that is both, a means of social distinction and of economic transaction. In symbolic terms, the money referred to the contested availability of the female body. On the other hand, in performative terms, positioning herself out of the actual market space on the ground, Kukama assumed the wafting center stage of money and value transaction. People gathered below her to collect the money, and the unexpectedly higher purchasing power of this clientele may have had an effect on the transactions and the "second economy" (Kukama \& Gaylard 2011) of the market itself. Her use of real money thus was not just a symbolic comment on the economic disparities in Jeppestown as it would have been with counterfeit notes but interfered directly into its economy, even though on a financially small scale.

Besides common currency used on an everyday basis such as the 10-Rand notes, Kukama also works with coins of low value that barely amounts to use as 
return money and almsgiving (such as one or two cent pieces). One example for her use of these coins is the Black Money Market (Fig. 5) installed for the 550th anniversary of the University of Basel (2010). In Johannesburg, she had bought with her Swiss artist fee a considerable quantity of coins from all over the world, all of which are still in circulation, but the demand is rather low considering their insignificant value. In her Black Money Market, she resold these coins. Each was packaged with a story, specifically narrated for the coin. The artist thus treated every piece as something special and distinctive. For instance, in referring to a coin's particular year of production or specific material features, she bestowed and invented a type of biography for the coins, not unlike Igor Kopykoff's notion of a 'biography of things' (1986). However, rather than describing a factual biography, she invented it. In doing so, she added an imaginative aspect that escapes the mere monetary value and instead turns each coin into an individual or unique protagonist within the global flows of material culture. ${ }^{11}$ The coin thus tended to lose its monetary value and instead adopted a cultural and symbolic value as mostly associated with souvenirs, personal gifts or art collections. Furnished with a story, the value of the coins increased considerably. Kukama accepted only strong currencies such as Euros, Pounds, Swiss Francs or US Dollars for the purchase of the coins and their story. This of course inflated the value of the coins symbolically but also in financial terms. The transaction altered exchange rates by the addition of an individual story for each coin, which was accompanied by a certificate of authenticity guaranteeing the buyer the "authenticity and uniqueness" of their new acquisition, pretty much as it is done on certain tourist markets (Fig. 6). In fact, the artist created a money market that goes against the rules of the usual exchange of foreign currency first by altering its traffic value by adding a specific story to the object, and secondly, by transforming a circulating object (qua currency) into a particular trinket, with its own object biography and personal attachment to its new owner. In its materiality, the coin became personalized and thus removed from circulation. This process appears in reverse to the injection of 10-Rand-notes into the Mai-Mai market in the Swing.

Kukama's work often entails exchange at conditions unusual for or even in contravention to the logics of the formal money economy. A third example is The 
Investment Bank of Elsewhere (2012), a performance she conceptualized on occasion of the COP17 climate change conference in Durban. It was performed at the Center for Historical Reenactment at August House in Johannesburg. Kukama had bought vegetables and fruit from informal street hawkers and resold them during the performance. For this, she had set up a big, square 'bank' counter in the center of which she placed herself, dressed in a business suit. Her clients were prompted to invest in a "piece of nature", i.e. the fruit or the vegetables that then would be certified for $10,20,30$ or 40 years (personal communication 4 January 2015). The certificate guaranteed that the client would find the "piece of nature" in "the same shape and condition as encountered today" whenever he or she returned to look at his/her investment (ibid.). The investment ranged from a minimum of 10 Rand upwards. Similar to the Black Money Market, the client invested not so much in a real commodity or value, but in the interaction with the artist and an abstract idea of maintaining or enhancing the value of an object that in fact is destined to decay. After all, different from what the certificate promises, the individual piece of fruit or vegetable will rot and can only live on as an abstract but certified asset or image. It is impossible for Kukama, the broker, to keep her promise. The investment therefore is a guarantee for the buyer's financial damage from the beginning. This kind of dazzlement resembles the machinations of the 'free market' that profits from the limited reserves of natural or mineral goods while acting as if they were inexhaustible. The poetic, playful, and interactional frame of the performance, however, lures art lovers willing to invest in something that is not much more than an inspired and critical idea. The 'asset' is of ideational value and considers resources different to the usual economic interests.

In her performances, Kukama uses actual money as a medium for rather fictitious or ideational transactions. Coins and bank notes of low value serve as a means of exchange for acquisitions that escape the actual money system and gain value rather by reflecting on or even generating social and cultural values in the moment of transaction. After all, the client's investment is a means for the artist to gain a little income and thus resembles ancient (and contemporary) forms of art patronage that worked on a long time contract with social obligations rather than object-specific transactions. For contemporary performance artists like Kukama, 
who refrain from feeding the art market with performance photographs and props, this is one of the few ways that their performances contribute to making a living.

\section{Money as a Signifier of the Alien}

Money, as a material, an emblem and a means of transaction, also refers to national and global identities and representations. While money is part of the global capital system, it also stands for particular regional and national identities, as seen above with Meschac Gaba's Dame game. Gerald Machona (born 1986 in Zvishane, Zimbabwe) refers to this dimension as he employs Zimbabwean dollars to reflect on national identification and social and political stigma. Machona has lived in the diaspora for over eight years now, mainly in South Africa, where he also obtained his art education. ${ }^{12}$ Different to Gaba, whose use of money as a medium in the 1990s only constituted one part of his general art practice, all of the work so far published and widely known by Machona involves paper money. It is in fact his signature material. However, as an artist working within Africa, and finding himself in a different socio-political situation than Gaba did 20 years earlier, Machona includes money in his work in a different way. He seems to be more interested in the social meaning of diverging national economies and trends of social and national disruptions within Africa.

In the economic realm, one such tension is reflected in money as a dividing and not a uniting force within the continent. Or as he says with reference to his film, performance, sculptural and photographic work:

What connects these mediums is firstly my exploration of paper money as an artistic or aesthetic material, and secondly my theoretic concerns, that grapple with issues of identity pertaining to Afrophobia, nationalism, cultural representation and migratory constructions of the African foreign national in Southern Africa (Gerald Machona in van Rensburg, 2013).

His interest thus lies less in the economic imbalance between the 'West' and the 'Global South,' but rather in the socio-economic and political contradictions of 
transnational migration, national policy and cultural identity politics in Africa and South Africa in particular. As a Zimbabwean based in South Africa, he is deeply troubled and concerned by the xenophobic attacks against 'foreigners' occurring mainly in poor neighborhoods in South Africa. They reached their culmination in May 2008, and more recently in April 2015, when several foreign nationals (mainly Zimbabweans and Mozambicans) were identified by their South African neighbors through their language, or by hearsay knowledge, and killed or injured. Many of these attacks are linked to the dissatisfaction of poor South African nationals about failures in governmental service, mainly in townships and poor settlements. ${ }^{13}$ Another element is the related frustration about the fact that freedom since 1994 has not necessarily ameliorated their chance for employment or a better economic status. What shocked many in these events is that foreigners were made out very much on the basis of random appearances such as a 'darker' skin or the imperfect mastery of isiZulu. This shows that many social identification practices rely on appearances, projections and prejudices whereby notions of class, the level of national(ist) identification and experiences of migration (or lack thereof) contribute to these very projections. The frustration about economic inequality thus is expressed in a dangerous scapegoating of the Other.

In response to these events, Machona has developed the Ndiri ('I am') figures that occupy jobs typically performed by the 'Other', by migrants in South Africa. The Ndiri have their head completely enveloped in a head mask of devalued Zimbabwe dollars, as for instance the Ndiri Barman (2010; Fig 7). This money mask conceals the face of the person wearing it (i.e. Machona himself who identifies with migrants) and replaces their identity by the outdated national currency of Zimbabwe. The Zimbabwean dollar had collapsed dramatically with hyper-inflation reaching 89.7 sextillion on 14 November 2008. As a result, the Zimbabwean economy broke down, leaving millions poor and with no means to buy food. Finally, foreign currencies were admitted in an effort to stabilize the economy and country, and still today, Zimbabwe does not have its own currency. Transactions occur with Euros, Dollars, Pounds and other internationally relevant currencies. This very economic crisis, linked to the already long-standing political crisis under Robert Mugabe, has forced an enormous amount of Zimbabweans to 
migrate to South Africa or constantly commute between the two countries in search of trading opportunities. ${ }^{14}$ By masking his performance figure with Zimbabwean money, Machona represents the ambivalent status of Zimbabweans as both losers within their own national economy and as a perceived foreign threat to the South African labor market. He denies himself an individual face and instead marks it with a national currency devoid of value. This can be interpreted in diverse ways, but most important, he elevates the devalued money to the position of individual identity.

The same character appears in the film Ita Kuti Kunaye (Make it rain, 2010). The title was inspired by the Shona lyric from the Bongo Maffin song, Mother I am going to Joburg with paper money (O'Toole 2013). In the film, Machona is dressed in a perfect black suit, black shoes and a black tie. His face is covered with Zimbabwean dollars and he dances on a rooftop high above the Road Port Terminal of Harare where most cross-border traders get a transport to border towns like Musina. The film runs in slow motion, and the money flying around finds its way miraculously into his hand and then his pockets-a hint that the film is played in the reverse. The sound is unidentifiable and can be interpreted as rather threatening. This is due to the fact that the sound is also running backward and in slow motion. Ita Kuti Kunaye is inspired by the Malawian dance Gule Wamkulu, which is performed in Chewa secret societies and has become a genre of identification among Chewa miners in African towns, adopting a certain subaltern and subversive connotation related to male migrant labour. The video therefore alludes to this subversive aspect of the foreigner by employing the Gule Wamkulu on the one hand and the extravaganza of throwing money around on the other. ${ }^{15}$

The concept of money as a signifier of the alien is also utilized in the more recent video Vabvakure (Shona for 'People from far away'), (2013; insert Fig. 8 here). The main figure in this piece is dressed in an astronaut costume made from decommissioned Zimbabwean dollars. The wearer of the costume is completely covered, wearing moon boots, also made from bank notes, and the head is covered with a darkened capsule. This helmet is rather small and therefore seems to replace the wearer's head rather than conceal it. Not one inch of skin can be seen, all of which reinforces the impression of this figure as something alien. It 
moves like a person in a nonthreatening and playful manner. But it lacks a facial identity, and also the fact that it does not speak makes it appear strange. It is unclear if the astronaut is African or European, black or white, male or female, human or alien. He looks humanoid and wears an apparently outdated astronaut costume-in fact, a historical object of human technology. The astronaut however does not appear as an earthly human departing to the cosmos, but rather looks like an alien exploring the earth-one of the Vabvakure, in fact, coming from far away.

The film shows how this foreign figure finds itself lying alone in a desert, apparently waking up from a blackout during arrival on the earth. He stands up, dances and then hoists his flag. Walking through the desert, he finds a Protea made from paper money (Fig. 9). ${ }^{16}$ The character takes it into his custody by placing it in a protective glass jacket and later feeds it water. Together with the flower, the astronaut explores the landscape and the urban spaces of South Africa where he encounters yet another astronaut in a money costume. Disappearing into a church hand in hand, it seems that two foreigners have found each other and want to unite in marriage. The church may however also allude to the role churches played as a harbor for victims in the periods of xenophobic aggressions.

The care and attention given to the Protea, one of the national symbols of South Africa, is striking. The astronaut nurtures and carries it through diverse areas of South Africa, from the pristine, dry desert through to the urban buzz, towards an open-ended future. The tender care demonstrates something profoundly human about an otherwise raceless, gender-neutral figure lacking any other identity-marking characteristics. It seems as if the foreigner clad in Zimbabwean bank notes is solely interested in preserving and protecting South Africa. Machona thus challenges ideas of social and national belonging with his Afronaut appearance. This anti-normative take is to some extent comparable to Athi-Patra Ruga's Beiruth series (Siegenthaler, 2009; Siegenthaler, 2013), but while Ruga adopts camp and drag aesthetics, Machona sticks to the pragmatics of universal dreams of space travel and money as a representative, but devalued national signifier. The currency used for the Protea, in this case the Zimbabwean dollar, may add to the identification of the astronaut as an Afronaut (as reflected in the use of African fabric in the eponymous photographic work of Cristina de Middel 
or in Yinka Shonibare's Space Walk, 2002 and Refugee Astronaut, 2015) ${ }^{17}$, but it also goes beyond this. The protagonist, as much as the places he goes to, do not necessarily represent a unified, pan-African or clichéd 'African' identity. Although Vabvakure transgress national and continental borders, their Zim-Dollar-costume associates them to the Zimbabwean nationality or economy and thus challenges the afro-futuristic promise and claim of overcoming such enforced spatial and national limitations of identity. ${ }^{18}$

The astronaut costume as a whole is reminiscent of an anachronistic nostalgia for the future; an outdated utopic dream, especially with the protective suit made from devalued Zimbabwean money. In Mary Corrigall's words, "[w]ith a suit made from decommissioned African currencies, he embodies not only an African, but a dated notion of what that might be“ (Corrigall, 2014). Money here is more of an out-dated material used in the present for the imagination of the future. This constellation of outdated material used in the present to imagine futures is typical for futuristic narratives. In this sense, money becomes the means of imagining a future by reconnecting to the past. In response to the frequent interpretation of his work as directed to the future or as being afro-futuristic, Machona states in an interview:

"So now that it has been framed as afrofuturistic which has its pros and cons for me, it is not about envisioning this future it is more about reconnecting with the past [sic]. The future for me being somewhere located in the distant past [...]" (Gbadamosi \& Machona, 2015, pp. 56-57).

This immediate connection of future and past is found in almost all myths through time and space. In Africa in particular, ancestors are addressed in order to receive advice about decisions concerning the present and the future. Mythical places such as the Nyau, to which Machona refers later in the quoted interview, also contain the future. Futurism for Machona is largely a mode to reconnect to a lost past that in turn serves to imagine futures. The suit from decommissioned Zimbabwe Dollars reflects the current identifications and conflicts arising through 
the contradiction between nationally defined economies and transnational social practice.

\section{Conclusion: Artist Signatures, Subversive Afrofuturism and the Artists' Place in Global Economy}

In this paper, I have looked at different ways money is used in the work of three contemporary artists: Meschac Gaba, Donna Kukama and Gerald Machona. In the case of Maschac Gaba, I emphasized his use of paper money as a moulding compound, confetti and objet trouvé, as a transformable material that tends to lose its iconic function once it is cut or shredded. However, his work also includes examples in which the symbolic and iconic function of paper money is at play, similar to the Zimbabwean dollar in the work of Gerald Machona. Here, money takes on the role of a signifier of identity, particularly national identity, in times of economic crisis and transnational migration. In Machona's work, money replaces human individuality by for instance covering the performer's face, and it thus gains importance on an iconic and symbolic rather than a material level. As the basis of the fabric of Vabvakure's astronaut costume, on the other hand, it also helps to imagine social and economic futures in which nationality becomes irrelevant for social distinction. In Donna Kukama's work, money remains a material basis for symbolic values and transactions. However, the money does not signify anything in itself but takes on the function of the transmitter and transformer; it is more of a catalyst than of a material asset. Only in the moment of transaction, of changing hands, does it generate value through the social and artistic interaction between the artist and the audiences she addresses.

Although all three artistic positions make use of money in distinct and different ways, they however can rely on a particular function of their material, which I would hesitantly describe as universal. I hesitate because to claim that paper money or coins are universal risks fostering the hegemony of a globalization in which local currencies have been replaced by a more or less unified money system. However, just because this global unification of money systems is a reality, the artists are able to address very diverse audiences. Their medium indeed means something to migrants from Zimbabwe, to traders in the Mai-Mai 
market and to the European museum visitors. Even when the paper bills represent a national identity and serve a particular national economy, their function as money and currency is more obvious to people in other parts of the world than are the beads or cowrie shells of ancient Benin.

I would like to conclude with an emphasis on the particularly contemporary features of these artistic practices involving money. They are relevant with regard to firstly, the iconographic potency of money in an increasingly international and globalized art world, secondly its signature function as a 'thumb print' of clearly identifiable artists, thirdly the role of currency in the transnational realities and modes of living of many contemporary African artists, and lastly its significance as an artistic point of reflection about the globalization of values and (art) markets. Money makes artworks easily accessible to different audiences because of its global presence. There is good reason to assume that Gaba's work found interest in the Rijksakademie voor Beeldende Kunsten in Amsterdam not least because it contained money - a transnational signifier that has symbolic power even when its exchange value is not known. Gerald Machona, too, spoke and still speaks to a broad audience using money. The events around the demise of the Zimbabwean dollar were so dramatic that they were broadcasted internationally even in newspapers and television programs that normally ignore news from the African continent. This omnipresent discourse about Zimbabwe's dwindling economy made Machona's pieces immediately recognizable. Although marked with a national identity, the dollar bills represent an international, and in fact, global 'iconography' or 'imagery' (in lack of a better word) that is understood by everyone. It can also reach people who have otherwise little to do with art but are participants in the money economy anywhere in the world. ${ }^{19}$ In this sense, the artists indeed speak to a global audience with a medium and aesthetics that relate to national and international identities at once.

Money also takes on a signature function in the work of artists and makes them easily recognizable. This is certainly the case with Gaba. Money appeared in almost every room of his Museum of Contemporary African Art, especially the Draft Room, the Salon and the Library. For instance, the entire interior of the Salon was decorated with the round cut-outs from paper money and immediately identified the 
object as an artwork by Gaba or part thereof. The same can be said about Machona, who is currently the artist most associated with devalued money. While it adopts its own meanings within the artwork, it is, too, the business card of the artist. The works are immediately identifiable as authored by him because of the use of paper money as such and the particular ways in which he crafts and includes it in his performances, the performance props, and his sculptural work that is sold to a gallery clientele. The repeated use of low-value coins in Kukama's performances $^{20}$ also has the potential to be associated with the artist herself, although generally, she uses other signature items in her work, such as a red suitcase, red shoes, a red dress or red sunglasses.

Apart from this signature function, money as an artistic material also refers to very real transnational socio-economic conditions that define the structures in which artists live and work. Their own mobility and status as migrants makes different currencies available to them, and it also makes them feel the economic power relations and cultural hegemonies related to currency exchange rates. Machona, as a Zimbabwean living in South Africa, has very directly experienced this interconnectivity of national identity and economic inequity due to gaping exchange rates. But expatriates like Gaba or contemporary African artists travelling to international residencies and performance events like Kukama also experience the divergent and often shocking differences in the value of currencies in their very own everyday life. For members of a highly mobile generation of artists like they are, currencies are an interesting medium to comment and reflect on the economies of their home and host countries, but also about their own social and political position within these transnational movements of people, money and values. $^{21}$

Not only the money and the artists, but also their work travels. Kukuma actively exported the low-value-coins, but also the actual performance, to Switzerland and traded them for strong currency. By introducing the devalued Zimbabwean currency in his works, Machona actually feeds the South African art market with a foreign currency, and also the individual museum spaces of Gaba's Museum for Contemporary African Art have traveled huge distances even between continents, reflecting the post-colonial condition of a diaspora artist. 
Finally, all three artists in some way allude to and play with both the financial markets and the global art market. By producing objects from decommissioned money and putting them on the art market, a revaluation of this money takes place because it is given a surplus aesthetic value. As an example, much of the art work analyzed in this paper has only been possible because of the Thomasson Effect, i.e. through the fact that something formerly very useful (a currency with a certain value in this case) becomes completely useless due to a change of the system (inflation as a failure of the structural adjustment program in 1990s Republic of Benin; inflation due to political and economic crisis in Zimbabwe in the 2000s; or small-piece weak currency within a strong South African or Swiss economy). Real and valid money is thus gained with this decommissioned money through the revaluation of the artwork as an object of surplus aesthetic and societal value.

This practice of making money acquired in informal and gray markets suitable for the art market by transforming it has a double nature of both subversion against and enormous adaptability to the value systems of the global economy and art markets.

Money thus proves to be a highly adaptive and popular medium for artistic practice in an era of globalization. In their largely standardized and globally accepted form, contemporary paper currency and coins fit easily into different national and even continental contexts. They are markers of political and economic crisis as much as they reflect the desire of artists and their audiences to participate in the global economy. Money as a social and economic asset-or lack thereof-, and as a cause of many political and social conflicts is a medium, symbol and material chosen by artists who try to engage the lived realities in African cities within ever increasing globalizing financial markets.

Although the artists themselves never refer explicitly to historical money systems and usages in Africa, there are, however, some interesting similarities. They use money as an artistic material, sourcing it from, transforming, and partly re-introducing it into the national and global economies. They attach specific social and cultural values to these transformed currencies and thus turn them into artworks that have a special representative and political status in society. Just as cowrie shells, glass beads or cloth used to serve as money and at some time left 
the economic circulation through storage in royal cowrie houses (akuehue in Dahomey; Law, 1999, p. 30) or insertion into prestige objects, the money they use leaves certain economies and value systems to enter other ones. It changes its role from the one of a currency to that of a cultural asset-an artwork-that can reenter other economical circuits. It is barely daring to claim that the workings of these contemporary art practices indeed resemble the political strategy of the $19^{\text {th }}$ century Benin kingdom (Ben-Amos, 1999, 118-138). The artists use money as a political strategy by transforming, inserting and retrieving currency and giving it added meaning in relation to the realms of life, art, identity, society, and the local and global economies. Just like the social and cultural practices surrounding traditional African currencies, the works presented by Meschac Gaba, Donna Kukama and Gerald Machona make use of currency in multiple ways, transforming it into assets of socio-political and cultural relevance without entirely withdrawing it from the global economic system.

Dr. des. Fiona Siegenthaler is a post-doc Senior Lecturer at the Chair of Social Anthropology, University of Basel, and a research associate at the Center for Visual Identities, Art and Design, University of Johannesburg. She is the coordinator and a co-researcher of the research project Art/Articulation: Art and the Formation of Social Space in African Cities (2015-2018; project lead Prof. Dr. Till Förster) funded by the Swiss National Science Foundation. In this framework, she continues her post-doctoral research in Kampala (Uganda).

Fiona.Siegenthaler@unibas.ch 


\section{Notes}

${ }^{1}$ I would like to thank Jordan Fenton for his helpful comments and suggestions to the first draft of this paper.

2 It was acquired by Tate Modern in 2012.

${ }^{3}$ See Pile ou Face (1993), reproduced in Revue Noire 18 (1995), p. 27.

${ }^{4}$ For reproductions, see Gaba et al. (2001), pp. 147-150.

${ }^{5}$ For images of the necklaces and design items, see Greenberg 2013, pp. 79-82.

6 Jane Guyer reports the case of Zaire in the 1990s when "briques" of paper money were made and counted in kilos rather than numbers (Guyer, 1995a, p. 3).

${ }^{7}$ Kukama is an artist and lecturer at the Wits University in Johannesburg. Besides her individual performance work, she is also involved in diverse collectives such as the Non-Non collective or the Center for Historical Reenactment (with Gabi Ngcobo and Kemang Wa Lehulere). She owns the Master of Arts in the Public Sphere (Sierre, 2008) and has been awarded Standard Bank Young Performance Artist 2013.

8 The piece is mainly known through video footage due to its ephemeral quality. However, according to the artist the work should be taken on its own (personal communication, 04.01.2015).

9 Although domestic abuse prevails, such aggressions also take place in public. Newspapers reported several incidences of discrimination and assaults on female commuters in the last years. As an example, see the article "Abusive, sexist taxi drivers criticised" of 28 February 2008 in the Independent Online (http://www.iol.co.za; last access: 14.10.2015).

10 The intervention ended in an unforeseen accident. The rope of the swing let loose, whereby Kukama fell down on the market place and broke her leg. The people collecting the money did not lend any attention to her and her health condition and instead ran off with the money.

11 She undertook similar operations in other performances such as e.g. in her performance First Museum of European Culture at the Museum der Kulturen in Basel where she asked museum visitors to offer her an object "from their culture" (personal communication 04.01.2015) in return for poems or songs performed by the artist. In another early performance, Red Suitcase, she sold individual items of her belongings stored in a red suitcase for an amount of money that in any case exceeded the actual value of the objects. In a more recent performance, Air-State Urgency, she walked the streets of Réunion with Yoga mats, inviting passers-by to lie down and choose a cloud to buy. This purchase would be, again, validated by a certificate.

12 Machona obtained his BA in 2009 Michaelis School of Arts Cape Town (fine art, new media), and his MA in 2013 at Rhodes University in Fine Art (sculpture). He is represented by the Goodman Gallery where further information is available: http://www.goodman-gallery.com/artists/geraldmachona (last access 16.01.2015) 
${ }^{13}$ Continued poverty and related frustration affect predominantly the black majority of South African nationals. It is a heavy legacy of white privilege and the related systematic denial of citizenship of the black population since pre-apartheid times until just two decades ago. It has become a habit in public discourse, therefore, to emphasize that most xenophobic attacks are by black nationals against black foreigners. However, since the 'black on black' discourse derives itself from the privileged white apartheid racial discourse and still has a strong tenacity, I prefer here to emphasize the economic condition rather than notions of race.

14 South Africa as an economic powerhouse directly abutting Zimbabwe has proved the most attractive destination of migrants, but Zimbabweans have also migrated to other neighboring states and to Europe and the USA. It is important to mention that the crisis in Zimbabwe is, like xenophobia in South Africa, directly related to failed postcolonial attempts at redressing the colonial history of white racism.

15 After the performance, Machona was detained and beaten (O'Toole 2013), an event that only confirms the subversive effect of the performance and the mask's material, the devalued Zim dollars.

16 The Protea is an autochthonous flower in South Africa and particularly the Cape regions and therefore stands as a symbol for the nation as such.

17 See de Middel, 2012 and http://www.yinkashonibarembe.com (last access 04.05.2016).

18 No matter how far the 'foreigner' figure comes from, Machona always is very aware of local and regional contexts when performing live. For instance, Machona made a performative intervention in St. Moritz (Switzerland) in his Vabvakure costume whereby the flower he carried was a local Edelweiss flower made from decommissioned Swiss, Portugese, Italian, Austrian and other European currencies. $\mathrm{He}$ thus referred to the permanent negotiation of the relationships between Switzerland and the European Union of which Switzerland is not a member, and the relationships between the EU member states.

19 One could even say that currency, as artistically produced graphic design object, represents the most widely circulated artworks on the planet. I would like to thank Sylvester Ogbechie for drawing my attention to this.

20 See for instance also in My piece of gold (2009), a performance designed for the Scenographies Urbaines festival in Johannesburg where the artist slowly dropped red coins on the floor of shops that had declared themselves willing to play a remade sound piece containing a text from Josef Conrad's Heart of Darkness.

21 As an example, Machona's Friend Best Girl's A Are Diamond's Blood: Bling Bling (2013) contains a Zimbabwean ten billion Dollar note, a Ghanaian 500 Cedi note, an old South African one Pound note, an Angolan 50 Escudos note, a Mozambican 100 Escudos note, all neatly folded into diamond shapes. It was presented at Goodman Gallery Johannesburg together with Y.O.L.O, In Profit We Trust? (2013) and A Sheet Of Cotton Paper Crumpled Into A Ball (2013). Each work was locked into a briefcase. 
The visitors were invited to try and crack the code. The successful candidate would win the artwork as a gift.

\section{REFERENCES}

Ben-Amos, Paula (1999). Art, Innovation, and Politics in Eighteenth-century Benin. Bloomington: Indiana University Press.

Blier, Suzanne Preston (1998). Royal Arts of Africa. The Majesty of Form. London: Lawrence King.

Corrigall, Mary (2014, June 22). Foreign Visitors. Gerald Machona Mediates on Alienation in his Latest Exhibition. The Sunday Independent. Retrieved from http://www.goodman-

gallery.com/files/upload/news/26894Newsforeignvisitorsbymarycorrigal.pdf (last access 05.05.2015).

De Middel, Cristina (2012). The Afronauts. Self-published.

Fibicher, Bernhard (Ed.). (2000). South Meets West. Kunsthalle Bern.

Gaba, Meschac et al. (Eds.). (2001). Museum of Contemporary African Art. Musée d'art contemporain africain. Amsterdam, New York: Artimo Foundation.

Gbadamosi, Raimi \& Machona, Gerald (2014). Gerald Machona in Conversation with Raimi Gbadamosi. In Goodman Gallery (Ed.), [Working Title] 2013 (pp. 5459). Johannesburg: Goodman Gallery.

Geary, Christraud M. (2011). Bamum. Milan: 5 Continents Editions (Visions of Africa).

Grabski, Joanna (2009). Urban Claims and Visual Sources in the Making of Dakar's Art World City. Art Journal, 68(1), pp. 7-23.

Greenberg, Kerryn (Ed.). (2013). Meschac Gaba. Museum of Contemporary African Art. London: Tate Publishing.

Guyer, Jane I. (Ed.). (1995). Money Matters. Instability, Values, and Social Payments in the Modern History of West African Communities. Portsmouth, $\mathrm{NH}$ : Heinemann and J. Currey. 
Guyer, Jane I. (1995a). Introduction. The Currency Interface and its Dynamics. In J. I. Guyer (Ed.), Money Matters. Instability, Values, and Social Payments in the Modern History of West African Communities (pp. 1-34). Portsmouth: Heinemann and J. Currey.

Hunkin, Jessica (2014, August 27). Gerald Machona and the Price of Society's Issues. Mail \& Guardian. Retrieved from http://mg.co.za/article/2014-08-27-geraldmachona-and-the-price-of-societys-issues (last access 05.05.2015).

Kopykoff, Igor (1986). The Cultural Biography of Things: Commoditization as Process. In A. Appadurai (Ed.), The Social Life of Things. Commodities in Cultural Perspective (pp. 64-91). New York: Cambridge University Press.

Kukama, Donna, \& Gaylard, Joseph (2011). Donna Kukama. The Swing (after after Fragonard). In A. Schrade (Ed.), Mine. A Selection of Films by South African Artists (n. p.). Berlin: Revolver.

Law, Robin (1999). Finance and Credit in Pre-colonial Dahomey. In E. Stiansen \& J. I. Guyer (Eds.), Credit, Currencies, and Culture. African Financial Institutions in Historical Perspective (pp. 15-37). Uppsala: Nordiska Afrikainstitutet.

O'Toole, Sean (2013). Bodies of Evidence. Artists Respond to Migration in Africa. Frieze 155, p. 24.

Perani, Judith \& Wolff, Norma Hackleman (1999). Cloth, Dress, and Art Patronage in Africa. Oxford: Berg.

Schrade, Anna (Ed.). (2011). Mine. A Selection of Films by South African Artists. Berlin: Revolver.

Siegenthaler, Fiona (2004). Wahrnehmung im Kontext: Das Museum of Contemporary African Art von Meschac Gaba. Entwurf einer 'installationsästhetischen' Methode im Spannungsfeld transkultureller Prozesse. Unpublished MA thesis. University of Basel, Basel.

Siegenthaler, Fiona (2009). Athi-Patra Ruga's Performances. Showing the Invisible Side of Public Space. In Athi-Patra Ruga \& Whatiftheworld Gallery (Eds.), AthiPatra Ruga: The Works 2006-2009 (pp. 7-15). Cape Town: Whatiftheworld Gallery. 
Siegenthaler, Fiona (2013). Visualizing the Mental City. The Exploration of Cultural and Subjective Topographies by Contemporary Performance Artists in Johannesburg. Research in African Literatures 44(2), pp. 163-176.

van Rensburg, Storm Janse (2013). Short Email Interview conducted with Gerald Machona for the Exhibition Project The Beautiful Ones, Berlin 2013. Retrieved from http://stormprojects.wordpress.com/biography/gerald-machona (last access 01.01.2015).

\section{Websites}

Meschac Gaba at Gallery Stevenson: http://www.stevenson.info/artists/gaba.html (last access 16.01.2015)

Homepage of the Museum of Contemporary African art: http://www.museumofcontemporaryafricanart.com/entree.html (last access 04.05.2015)

Donna Kukama at blank projects:

www.blankprojects.com/artists/donna-kukama (last access 05.05.2015)

Gerald Machona at Goodman Gallery: http://www.goodman-gallery.com/artists/geraldmachona (last access 16.01.2015) 